This is the author's final, peer-reviewed manuscript as accepted for publication. The publisher-formatted version may be available through the publisher's web site or your institution's library.

\title{
Weight control and cancer preventive mechanisms: role of IGF-1-mediated signaling pathways
}

Linglin Xie and Weiqun Wang

\section{How to cite this manuscript}

If you make reference to this version of the manuscript, use the following information:

Xie, L., \& Wang, W. (2013). Weight control and cancer preventive mechanisms: Role of IGF-1-mediated signaling pathways. Retrieved from http://krex.ksu.edu

\section{Published Version Information}

Citation: Xie, L., \& Wang, W. (2013). Weight control and cancer preventive mechanisms: Role of insulin growth factor-1-mediated signaling pathways. Experimental Biology and Medicine, 238(2), 127-132.

Copyright: (c) 2013 Society for Experimental Biology and Medicine

Digital Object Identifier (DOI): doi:10.1177/1535370213477602

Publisher's Link: http://ebm.rsmjournals.com/content/238/2/127.full

This item was retrieved from the K-State Research Exchange (K-REx), the institutional repository of Kansas State University. K-REx is available at http://krex.ksu.edu 
1 Weight control and cancer preventive mechanisms: role of IGF-1-mediated

2 signaling pathways

3 Linglin $\mathrm{Xie}^{1,2}$ and Weiqun Wang ${ }^{2}$

$4 \quad{ }^{1}$ Department of Biochemistry and Molecular Biology, University of North Dakota, Grand

5 Forks, ND 58202, USA; ${ }^{2}$ Department of Human Nutrition, Kansas State University,

6 Manhattan, KS 66506, USA

7 Corresponding authors: Linglin Xie or Weiqun Wang, Department of Biochemistry and

8 Molecular Biology, University of North Dakota, Grand Forks, ND 58202, USA; or

9 Department of Human Nutrition, Kansas State University, Manhattan, KS 66506, USA.

10 Emails: linglin.xie@med.und.edu or wwang@ksu.edu

11 Abbreviations used: DCR: dietary calorie restriction; IGF-1: Insulin-like growth factor-1; DMBA:

12 7,12-Dimethylbenz(a)anthracene; ACS: American Cancer Society; VEGF: vascular endothelial

13 growth factor; FGF: fibroblast growth factor; JNK: Jun N-terminal Kinases; TPA: 2-O-

14 tetradecanoylphorbol-13-acetate; LID: Liver IGF-1-deficient. 
2 Overweight and obese not only increase the risk of cardiovascular disease and type-2

3 diabetes mellitus, but are also now known risk factors for a variety of cancers. Weight

4 control, via dietary calorie restriction (DCR) and/or exercise, has been demonstrated to

5 be beneficial for cancer prevention in various experimental models, but the underlying

6 mechanisms are still not well defined. Recent studies conducted in a mouse skin

7 carcinogenesis model show that weight loss induced a significant reduction of the

8 circulating levels of IGF-1 and other hormones, including insulin and leptin, resulting in

9 reduced IGF-1-dependent signaling pathways, i.e., Ras-MAP-proliferation and Akt-

10 PI3K-antiapoptosis. Selective targeting IGF-1 to Akt/mTOR and AMPK pathways, via

11 negative energy balance, might inactivate cell cycle progression and ultimately

12 suppress tumor development. This review highlights the current studies focused on the

13 major role of reducing IGF-1-activated signaling via weight control as a potential cancer

14 preventive mechanism.

15 Keywords: weight control, dietary calorie restriction, exercise, cancer prevention, IGF-1

16 signaling

17 Short Title: IGF-1 Pathways and Cancer Prevention

\section{Introduction}

Maintaining a healthy body weight emerges as a strategy to generally reduce cancers

21 and has also been suggested to reduce cancer risk. With the increasing prevalence of 
1 obesity in both adults and children, it is important to identify the mechanism underlying

2 cancer prevention via weight control. Current studies have focused on how understanding the molecular mechanisms of weight control, via dietary calorie

4 restriction (DCR) and/or physical exercise, in both mouse model and human studies,

5 prevent cancer. These studies will lead to future chemoprevention strategies for cancer.

\section{Overweight/obesity as a risk factor of cancer}

7 It is well known that obesity has a substantial influence on the development of many

8 chronic diseases, including cancer. Numerous prospective and case-control studies that

9 address the effect of body weight on cancer risk, estimate that excess body weight and

10 sedentary life style account for about $39 \%$ of endometrial, $25 \%$ of kidney, $11 \%$ of colon,

$119 \%$ of postmenopausal breast cancer, and $5 \%$ of total cancer incidence. ${ }^{1}$ The

12 prevalence of obesity in the U.S. rose to approximately $25 \%$ and is projected to

13 increase to more than $40 \%$ by 2030 . In children and adolescents between the ages of 6

14 and 17 years, the prevalence of obesity appears to be increasing even more rapidly

15 than in adults in industrialized and developing countries. ${ }^{2}$ It has been suggested that those who are $25 \%$ over normal weight have a $33 \%$ greater cancer risk than those who

17 maintain an ideal body weight. ${ }^{3}$ Therefore, weight control to prevent obesity has been recommended as a strategy for reducing cancer risk by the American Cancer Society (ACS) as early as 1996.

In obese patients and animals, insulin/leptin resistance, inflammation, and

21 changes in hormone and growth factor concentrations are found to be key pathogenic

22 factors that lead to many types of cancer, including breast, colon, pancreas, and 
endometrium. These hormones, or growth factors, include insulin, leptin, and Insulin growth factor-1(IGF-1). They directly or indirectly provide a mitogenic effect in many cell types, especially in pre-neoplastic cells, by inducing proliferative and anti-apoptotic mechanisms..$^{4-6}$ In vitro studies demonstrate that insulin, through binding to the insulin receptor, increases neoplastic proliferation at both physiological and pharmacological doses. ${ }^{7-9}$ Recently, hyperinsulinemia associated with the IGF-1 signaling pathway has been widely studied, and the condition strongly stimulates the development and growth of several tumors, especially in breast cancer. ${ }^{10-12}$ Hyperinsulinemia is associated with increased circulating free sex hormones, such as estrogen and androgen, via inhibiting the hepatic production of sex hormone-binding globulin. ${ }^{13}$ Altered adipokine production is also associated with insulin resistance. Adiponectin, one of the most abundant adipokines, is shown to be both anti-angiogenic and anti-inflammatory, and is lower in circulation in both obese and cancer patients. ${ }^{14-18}$

A high level of serum leptin in obese patients has been associated with increased cellular proliferation and angiogenesis across a wide variety of cancer subtypes, including colon, prostate and breast cancer. ${ }^{19-25}$ The role of leptin in vascular remodeling may be independent of or coupled with vascular endothelial growth factor (VEGF) and fibroblast growth factor (FGF). ${ }^{26}$ Additionally, leptin stimulates several types of pre-neoplastic and neoplastic cells by mediating IGF-1R, resulting proliferation ${ }^{27-29}$ and/or anti-apoptosis. ${ }^{30-32}$

Levels of proinflammatory cytokines, including IL-6, TNF- $\alpha$ and IL-1 $\beta$, are found to be higher in obese mice and humans. Adipose tissue is a major source for these cytokines, contributing up to $35 \%$ of circulating IL-6. ${ }^{33}$ Levels of these cytokines are also 
1 elevated in cancer patients. ${ }^{34,35}$ Although it is still unclear how these cytokines play a

2 combined role in tumorigenesis, activation of NF-kB and STAT3 seem to be likely

3 associated. $^{36-41}$

4 Weight control via DCR inhibits tumor development in rodents

5 DCR is the most efficient method of weight control. The first work to show that incidence

6 of tumors in mice positively correlated with food intake was published in 1944 by Tui

7 and colleagues. ${ }^{42}$ To date, DCR has been the most widely studied and most potent,

8 broadly acting dietary intervention for cancer prevention in various experimental

9 models. ${ }^{43,44}$ DCR is a dietary regimen that restricts calorie intake without malnutrition

10 (usually by $20 \%-40 \%$ relative to ad libitum-fed controls from lipids and carbohydrates,

11 but same amount of proteins, micronutrients and minerals, etc.). DCR-fed wildtype

12 animals are typically healthier, live longer, and more active than their ad libitum-fed

13 counterparts ${ }^{45}$.

DCR inhibits various spontaneous tumor developments in experimental animals.

15 In rodents, a $20-40 \%$ below the usual ad libitum intake initiated early in life led to approximately $20-60 \%$ reduction in tumor incidence, including tumors of mammary, liver,

17 colon, skin, pancreas, bladder, and leukemia. ${ }^{46,47}$ In p53-deficient mice, both juvenile-

18 and adult-initiated calorie restriction to $60 \%$ of ad libitum intake, significantly delayed

19 tumor development. ${ }^{48,49}$ In $A p c^{\mathrm{Min}}$ mice, calorie intake restricted by $40 \%$ of the ad

20 libitum-fed mice reduced intestinal polyps by $57 \% .{ }^{49,50}$ DCR is also well documented to

21 suppress carcinogen-induced carcinogenesis, like benzo( $\alpha$ )pyrene ${ }^{51}$ and 7,12 -

22 dimethylbenz $(\alpha)$ anthracene $(\mathrm{DMBA})^{52}$. 


\section{Weight control via exercise}

2 Epidemiological studies report that physical activity can reduce the risk of many types of

3 cancers, especially cancer of the prostate, breast, endometrial, and lung. ${ }^{53}$ Evidence

4 suggests that 4-7 hours per week of moderate to vigorous physical activity is required

5 for adequate risk reduction. ${ }^{53}$ However, in the U.S., adults are not achieving the

6 recommended amounts of physical activity, according to ACS guidelines. ${ }^{54-59}$

Despite the large numbers of studies conducted, cancer prevention by physical

8 activity in animal models is not consistent. This is largely due to the lack of precise

9 quantitative characteristics of duration and intensity of exercise as well as the control of

10 the dietary calorie intake. Therefore, the impact of exercise on cancer development

11 should be considered in combination with an isocaloric diet.

\section{Decreased IGF-1 signaling in cancer prevention}

13 There are several hypotheses describing mechanisms by which weight control via DCR

14 and/or exercise may reduce tumor development. Some hypotheses include decreased

15 oncogene expression, improved DNA repair, enhanced scavenging of reactive oxygen

16 species, and altered levels of cancer-related hormones. ${ }^{60}$

Hormone alteration seems to be a critical factor for cancer prevention by weight

18 control, due to the significant role of hormones in regulating cellular growth. Previous

19 researchers have found that the levels of IGF-1 ${ }^{62-64}$, insulin ${ }^{61}$, and leptin ${ }^{61,65-67}$

20 decreased significantly in rodents in response to DCR. 
IGF-1 is a major endocrine and paracrine regulator of cellular growth and metabolism. Binding of IGF-1 to IGF-1R activates many signaling pathways, including Jun N-terminal Kinases (JNK), p38 MAPK and PI3K via activation of receptor tyrosine kinases and/or the Ras proto-oncogene, to mediate suppression of apoptosis and contribute proliferation and cell growth. ${ }^{74-78}$ IGF-1R is overexpressed in many tumors. ${ }^{70,71}$ Abundant epidemiologic evidence supports the hypothesis that IGF-1 is involved in several types of human cancers. ${ }^{68,69}$ Adult HK1.IGF-1 mice that overexpressed IGF-1 spontaneously developed papillomas faster than non-transgenic littermates. $^{72,73}$ Adult HK1.IGF-1 mice showed enhanced signaling through the Akt/mTOR pathways ${ }^{79}$, which suggested a critical role of IGF-1 in activating Akt/mTOR pathway that regulates cell proliferation, survival and energy metabolism. Activated mTOR signaling through the Akt/mTOR pathway in Akt overexpressing mouse caused alterations in epidermal proliferation and differentiation. ${ }^{79}$ The mice are more sensitive to topical 12-O-tetradecanoylphorbol-13-acetate (TPA) treatment. Activation of IGF-1R also indirectly acts with other cancer-related molecules, such as p53, known to arrest cell growth and induce apoptosis with increased levels of p21 and reduced Bcl-2. ${ }^{80}$

Reduction in glucose and insulin levels, as well as IGF-1, has been well documented in DCR-fed mice from different labs. Levels of circulating IGF-1 are influenced by dietary energy intake, which may be due to changing growth hormoneregulated hepatic synthesis of IGF-1. ${ }^{81}$ Restoration of IGF-1 in p53-deficient mice reversed DCR-induced cancer protection, suggesting a requirement of reduced levels of IGF-I. ${ }^{16}$ While 20\% DCR-fed SENCAR mice showed a significant reduction of plasma IGF-1 levels, a remarkable decrease of IGF-1-dependent Ras/MAPK and PI3K/Akt 
1 signaling was demonstrated in TPA-stimulated skin tissues. ${ }^{82,83}$ Both down-expression

2 of PCNA as a biomarker of proliferation and up-expression of Caspase-3 as a

3 biomarker of apoptosis were also subsequently found in those mice..$^{82,83}$

Diet-induced changes in Akt/mTOR signaling have been reported in various

5 organ tissues (i.e., liver, skin epidermis, and mammary fat pad). DCR-induced increase of AMP/ATP ratio may inhibit AMPK signaling that regulates mTOR activity and thereby

7 inhibits the targeted protein production. These changes appear to be related to the reduction of circulating IGF-1 levels. In such study, 30\% DCR regimen for 15-17 weeks

9 is sufficient to lower circulating IGF-1 concentrations and inactivate Akt and mTOR

10 signaling in multiple epithelial tissues, regardless of genetic background of the

11 experimental mice. ${ }^{84}$ These results suggest that DCR induced a decrease of IGF-1

12 should play a central role in response with negative energy balance-altered depression

13 of mTOR activity. ${ }^{85}$

In addition, an important study has revealed that DCR contributes to mammalian cell survival by inducing Sirtuin 1 (SIRT1) deacetylase, which deacetylates the DNA repair factor Ku70. Ku70 can prevent the proapoptotic factor Bax from mitochondrial

17 entry, therefore inhibiting stress induced apoptosis. ${ }^{86}$ This impact is probably mediated by insulin/IGF-1 because treatment with insulin and/or IGF-1 can reduce SIRT1 deacetylase expression. ${ }^{86}$

In humans, 15 weeks of moderate exercise changes the levels of fasting insulin,

21 glucose, IGF-I, IGF-II, IGFBP-1, IGFBP-3, and IGF-I:IGFBP-3 molar ratio. ${ }^{87,88}$ However,

22 a 12-month exercise regimen did not change IGF-1 and IGFBG-3 levels in 
1 postmenopausal women. ${ }^{89}$ Regular exercise alters the serum IGF-1 axis in vivo and reduces prostate (LNCaP) tumor cell proliferation by enhancing the function of the p53 gene ${ }^{90,91}$ In SENCAR mice, weight loss by 10 -week physical activity with iso-caloric intake as sedentary controls was able to inhibit PI3K signaling and increase caspase-3 activity. ${ }^{82}$ These effects were partially reversed by IGF-1 restoration. ${ }^{82}$ Microarray analysis comparing TPA-induced gene expression profiles in DCR- or exercise-treated mouse skin tissues revealed 411 genes affected by DCR versus only 67 affected by exercise with iso-caloric intake, including PI3K and MAPK pathway genes. ${ }^{82-83}$ Similar results of mammary gland gene expression are found in C57BL/6 mice with a 30\% DCR versus exercise..$^{92}$ The increased expression of fatty acid elongase-1 in treadmill exercised mice with iso-caloric intake suggests that exercise may affect the phospholipid profile. ${ }^{93}$ In addition, a lipidomics study using electrospray ionizationtandem mass spectrometry demonstrated that 57 phospholipids were significantly changed among a total of 338 species detected, and 25 species were closely related to exercise by a stepwise discriminant analysis. ${ }^{93-94}$ These combined results indicate that DCR and/or exercise may target IGF-1-dependent signaling directly for a potential cancer prevention.

\section{IGF-1 signaling as a potential target for cancer prevention}

Effective prevention and treatment strategies are urgently needed for anti-tumorigenesis. Considering the central role that IGF-1 played on cancer development, decreasing IGF1 signaling either by chemical intervention or genetic interference has been intensively studied. Liver IGF-1-deficient (LID) mice have been utilized to mimic the effect of DCR on reducing circulating IGF- $1 .{ }^{95}$ These mice had about $75 \%$ reduction in the level of 
1 circulating IGF-1. Repressed IGF-1R, EGFR and Akt/mTOR were observed in the skin

2 tissue of LID mice after TPA treatment. LID mice initiated with DMBA and promoted with

3 TPA, developed fewer and slower growing of papillomas compared with untreated

4 littermates. ${ }^{95}$ In another study that tested if DCR effect can be replicated by

5 chemotherapy, mice transplanted with Panc02 murine pancreatic cancer cell were

6 treated with either DCR or rapamycin for 20 weeks. ${ }^{96}$ Rapamycin treatment $(2.5 \mathrm{mg} / \mathrm{kg}$

7 intraperitoneal every other day) did not decrease body weight, IGF-1 or leptin level,

8 unlike DCR, but inhibited glucose responsiveness. Mice that received rapamycin had

9 depressed mTOR signaling and had significantly reduced tumor volume compared to

10 untreated mice, although to a lesser extent than DCR-fed mice. These results suggest

11 that the downstream modulators of IGF-1 pathway can be a potential target for cancer

12 prevention supplements.

13 Conclusion

14 Many epidemiological, clinical, and experimental studies have revealed a positive

15 relationship between weight control via DCR or physical activity, and the frequency of

16 various cancers. Reductions in the levels of circulating IGF-1 and other mitogenic

17 hormones/growth factors, including insulin and leptin induced by DCR or physical

18 activity, efficiently inactivate the downstream signaling pathways via IGF-1R as

19 summarized in details in Figure 1. Future studies aimed at further elucidating the

20 mechanisms underlying the cancer prevention possibilities of weight control may finally

21 lead to efficient pharmacologic approaches that can be used alone or combined with

22 weight control. 
1 Author contributions: LX and WW were responsible for writing and revising the

2 manuscript.

\section{Acknowledgements}

4 WW is supported in part by grants from NIH R15CA167678, NIH-INBRE P20RR16475,

5 NIH R01CA106397, and the Terry Johnson Center for Basic Cancer Research, Kansas

6 State University. LX is supported by grants from NIH National Center for Research

7 Resources 5P20RR016471-12/8 and P20GM103442-12. WW also provides a journal

8 contribution \#13-055-J of the Kansas Agricultural Experiment Station. 
1 Figure legend:

2 Figure 1. Schematic illustration of IGF-1- and/or leptin-induced signaling pathways that

3 may be targeted by weight control via dietary calorie restriction and exercise. 


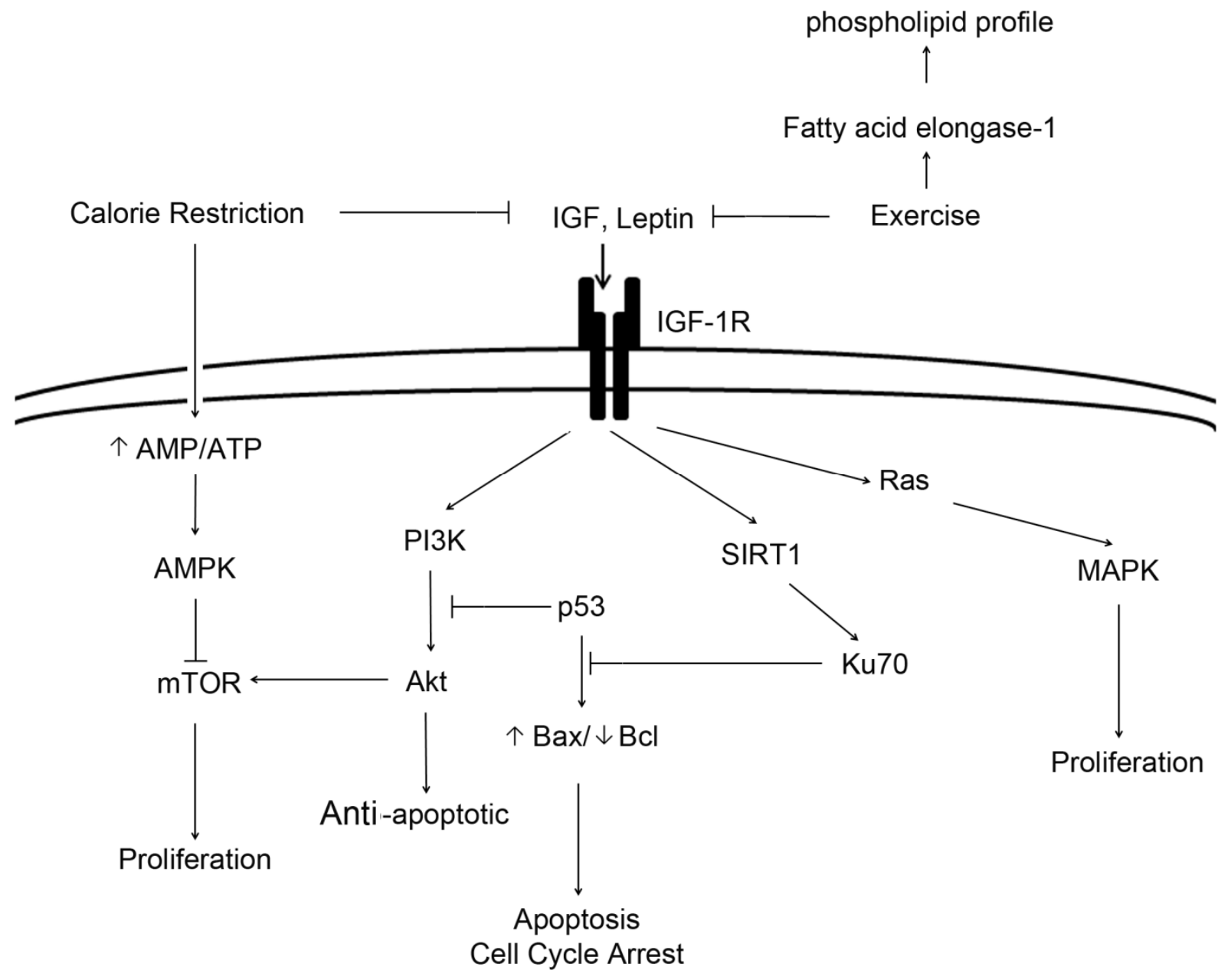

1

2 


\section{References}

1. Bergstrom A, Pisani P, Tenet V, Wolk A, Adami HO: Overweight as an avoidable cause of cancer in Europe. Int J Cancer 2001, 91:421-430.

2. Vainio $\mathrm{H}$, Kaaks $\mathrm{R}$, Bianchini $\mathrm{F}$ : Weight control and physical activity in cancer prevention: international evaluation of the evidence. Eur J Cancer Prev 2002, 11:S94-100.

3. Kritchevsky D: Diet and cancer: what's next? J Nutr 2003, 133:3827S-3829S.

4. Al-Aubaidy HA, Jelinek HF: Oxidative DNA damage and obesity in type 2 diabetes mellitus. Eur J $8 \quad$ Endocrinol 2011, 164:899-904.

9 5. Zhang H, Xie C, Spencer HJ, Zuo C, Higuchi M, Ranganathan G, Kern PA, Chou MW, Huang Q,

6. Dai Q, Gao YT, Shu XO, Yang G, Milne G, Cai Q, Wen W, Rothman N, Cai H, Li H et al: Oxidative stress, obesity, and breast cancer risk: results from the Shanghai Women's Health Study. J Clin Oncol 2009, 27:2482-2488.

7. Stuart CA, Prince MJ, Peters EJ, Smith FE, Townsend CM, 3rd, Poffenbarger PL: Insulin receptor proliferation: a mechanism for tumor-associated hypoglycemia. J Clin Endocrinol Metab 1986, 63:879-885.

8. Pavelic K: Aplastic carcinoma in diabetic mice: hyperglycemia-suppressed proliferation rate and insulin synthesis by tumor cells. J Natl Cancer Inst 1979, 62:139-141.

9. Osborne $\mathrm{CK}$, Bolan G, Monaco ME, Lippman ME: Hormone responsive human breast cancer in long-term tissue culture: effect of insulin. Proc Natl Acad Sci U S A 1976, 73:4536-4540.

10. Dunn SE, Hardman RA, Kari FW, Barrett JC: Insulin-like growth factor 1 (IGF-1) alters drug sensitivity of HBL100 human breast cancer cells by inhibition of apoptosis induced by diverse anticancer drugs. Cancer Res 1997, 57:2687-2693.

11. Dunn SE, Kari FW, French J, Leininger JR, Travlos G, Wilson R, Barrett JC: Dietary restriction reduces insulin-like growth factor I levels, which modulates apoptosis, cell proliferation, and tumor progression in p53-deficient mice. Cancer Res 1997, 57:4667-4672.

12. Jernstrom H, Sandberg T, Bageman E, Borg A, Olsson H: Insulin-like growth factor-1 (IGF1) genotype predicts breast volume after pregnancy and hormonal contraception and is associated with circulating IGF-1 levels: implications for risk of early-onset breast cancer in young women from hereditary breast cancer families. Br J Cancer 2005, 92:857-866.

13. Poretsky L, Kalin MF: The gonadotropic function of insulin. Endocr Rev 1987, 8:132-141.

14. Goodwin PJ, Ennis M, Pritchard KI, Trudeau ME, Koo J, Taylor SK, Hood N: Insulin- and obesityrelated variables in early-stage breast cancer: correlations and time course of prognostic associations. J Clin Oncol 2012, 30:164-171.

15. Goodwin PJ, Stambolic V: Obesity and insulin resistance in breast cancer--chemoprevention strategies with a focus on metformin. Breast 2011, 20:S31-35.

16. Gallagher EJ, LeRoith D: Insulin, insulin resistance, obesity, and cancer. Curr Diab Rep 2010, 10:93-100. 
1 17. Smith MR, Lee H, Fallon MA, Nathan DM: Adipocytokines, obesity, and insulin resistance during $2 \quad$ combined androgen blockade for prostate cancer. Urology 2008, 71:318-322.

3 18. Rose DP, Komninou D, Stephenson GD: Obesity, adipocytokines, and insulin resistance in breast $4 \quad$ cancer. Obes Rev 2004, 5:153-165.

19. Koda M, Sulkowska M, Kanczuga-Koda L, Cascio S, Colucci G, Russo A, Surmacz E, Sulkowski S: Expression of the obesity hormone leptin and its receptor correlates with hypoxia-inducible factor-1 alpha in human colorectal cancer. Ann Oncol 2007, 18:vi116-119.

20. Chung WK, Leibel RL: The links between obesity, leptin, and prostate cancer. Cancer J 2006, 12:178-181.

21. Stattin P, Lukanova A, Biessy C, Soderberg S, Palmqvist R, Kaaks R, Olsson T, Jellum E: Obesity and colon cancer: does leptin provide a link? Int J Cancer 2004, 109:149-152.

22. Kos K, Wong S, Tan B, Gummesson A, Jernas M, Franck N, Kerrigan D, Nystrom FH, Carlsson LM, Randeva HS et al: Regulation of the fibrosis and angiogenesis promoter SPARC/osteonectin in human adipose tissue by weight change, leptin, insulin, and glucose. Diabetes 2009, 58:17801788.

23. Anagnostoulis S, Karayiannakis AJ, Lambropoulou M, Efthimiadou A, Polychronidis A,

24. Park HY, Kwon HM, Lim HJ, Hong BK, Lee JY, Park BE, Jang Y, Cho SY, Kim HS: Potential role of leptin in angiogenesis: leptin induces endothelial cell proliferation and expression of matrix metalloproteinases in vivo and in vitro. Exp Mol Med 2001, 33:95-102.

25. Hoda MR, Keely SJ, Bertelsen LS, Junger WG, Dharmasena D, Barrett KE: Leptin acts as a mitogenic and antiapoptotic factor for colonic cancer cells. Br J Surg 2007, 94:346-354.

26. Cao R, Brakenhielm E, Wahlestedt C, Thyberg J, Cao Y: Leptin induces vascular permeability and synergistically stimulates angiogenesis with FGF-2 and VEGF. Proc Natl Acad Sci U S A 2001, 98:6390-6395.

27. Ogunwobi OO, Beales IL: Cyclo-oxygenase-independent inhibition of apoptosis and stimulation of proliferation by leptin in human colon cancer cells. Dig Dis Sci 2007, 52:1934-1945.

28. Pai R, Lin C, Tran T, Tarnawski A: Leptin activates STAT and ERK2 pathways and induces gastric cancer cell proliferation. Biochem Biophys Res Commun 2005, 331:984-992.

29. Miyazaki T, Bub JD, Iwamoto Y: c-Jun NH(2)-terminal kinase mediates leptin-stimulated androgen-independent prostate cancer cell proliferation via signal transducer and activator of transcription 3 and Akt. Biochim Biophys Acta 2008, 1782:593-604.

30. Naviglio S, Di Gesto D, Romano M, Sorrentino A, Illiano F, Sorvillo L, Abbruzzese A, Marra M, Caraglia $M$, Chiosi $E$ et al: Leptin enhances growth inhibition by cAMP elevating agents through apoptosis of MDA-MB-231 breast cancer cells. Cancer Biol Ther 2009, 8:1183-1190.

31. Shen $Y$, Wang $Q$, Zhao $Q$, Zhou J: Leptin promotes the immune escape of lung cancer by inducing proinflammatory cytokines and resistance to apoptosis. Mol Med Report 2009, 2:295299.

32. Rouet-Benzineb P, Aparicio T, Guilmeau S, Pouzet C, Descatoire V, Buyse M, Bado A: Leptin counteracts sodium butyrate-induced apoptosis in human colon cancer HT-29 cells via NFkappaB signaling. J Biol Chem 2004, 279:16495-16502. 
33. Fenton JI, Birmingham JM: Adipokine regulation of colon cancer: adiponectin attenuates interleukin-6-induced colon carcinoma cell proliferation via STAT-3. Mol Carcinog 2010, 49:700-709.

34. Kai H, Kitadai Y, Kodama M, Cho S, Kuroda T, Ito M, Tanaka S, Ohmoto Y, Chayama K: Involvement of proinflammatory cytokines IL-1beta and IL- 6 in progression of human gastric carcinoma. Anticancer Res 2005, 25:709-713.

35. Punnonen J, Heinonen PK, Kuoppala T, Jansen CT, Punnonen R: Production of interleukin-1 beta and tumour necrosis factor-alpha in patients with benign or malignant ovarian tumours. $J$ Cancer Res Clin Oncol 1991, 117:587-592.

36. Syed V, Ulinski G, Mok SC, Ho SM: Reproductive hormone-induced, STAT3-mediated interleukin 6 action in normal and malignant human ovarian surface epithelial cells. $J$ Natl Cancer Inst 2002, 94:617-629.

37. Sriuranpong V, Park JI, Amornphimoltham P, Patel V, Nelkin BD, Gutkind JS: Epidermal growth factor receptor-independent constitutive activation of STAT3 in head and neck squamous cell carcinoma is mediated by the autocrine/paracrine stimulation of the interleukin 6/gp130 cytokine system. Cancer Res 2003, 63:2948-2956.

38. Li Q, Zhou XD, Kolosov VP, Perelman JM: Nicotine reduces TNF-alpha expression through a alpha7 nAChR/MyD88/NF-kB pathway in HBE16 airway epithelial cells. Cell Physiol Biochem 2011, 27:605-612.

39. Ryazantseva NV, Novitskii VV, Zhukova OB, Biktasova AK, Chechina OE, Sazonova EV, Radzivil TT, Wice AN, Chasovskikh NY: Role of NF-kB, p53, and p21 in the regulation of TNF-alpha mediated apoptosis of lymphocytes. Bull Exp Biol Med 2010, 149:50-53.

40. Crinelli R, Antonelli A, Bianchi M, Gentilini L, Scaramucci S, Magnani M: Selective inhibition of NF-kB activation and TNF-alpha production in macrophages by red blood cell-mediated delivery of dexamethasone. Blood Cells Mol Dis 2000, 26:211-222.

41. Xu YX, Pindolia KR, Janakiraman N, Chapman RA, Gautam SC: Curcumin inhibits IL1 alpha and TNF-alpha induction of AP-1 and NF-kB DNA-binding activity in bone marrow stromal cells. Hematopathol Mol Hematol 1997, 11:49-62.

42. Tui C, Wright AM, Mulholland JH, Carabba V, Barcham I, Vinci VJ: Studies on Surgical Convalescence I-Sources of Nitrogen Loss Postgastrectomy and Effect of High Amino-Acid and High Caloric Intake on Convalescence. Ann Surg 1944, 120:99-122.

43. Hursting SD, Kari FW: The anti-carcinogenic effects of dietary restriction: mechanisms and future directions. Mutat Res 1999, 443:235-249.

44. Hursting SD, Lashinger LM, Colbert LH, Rogers CJ, Wheatley KW, Nunez NP, Mahabir S, Barrett JC, Forman MR, Perkins SN: Energy balance and carcinogenesis: underlying pathways and targets for intervention. Curr Cancer Drug Targets 2007, 7:484-491.

45. Hursting SD, Lavigne JA, Berrigan D, Perkins SN, Barrett JC: Calorie restriction, aging, and cancer prevention: mechanisms of action and applicability to humans. Annu Rev Med 2003, 54:131152.

46. Albanes D: Total calories, body weight, and tumor incidence in mice. Cancer Res 1987, 47:19871992. 

1 47. Roebuck BD, Yager JD, Jr., Longnecker DS, Wilpone SA: Promotion by unsaturated fat of 2 azaserine-induced pancreatic carcinogenesis in the rat. Cancer Res 1981, 41:3961-3966.
3 48. Berrigan D, Perkins SN, Haines DC, Hursting SD: Adult-onset calorie restriction and fasting delay
49. Hursting SD, Perkins SN, Brown CC, Haines DC, Phang JM: Calorie restriction induces a p53- independent delay of spontaneous carcinogenesis in p53-deficient and wild-type mice. Cancer Res 1997, 57:2843-2846.
50. Mai V, Colbert LH, Berrigan D, Perkins SN, Pfeiffer R, Lavigne JA, Lanza E, Haines DC, Schatzkin A, Hursting SD: Calorie restriction and diet composition modulate spontaneous intestinal tumorigenesis in Apc(Min) mice through different mechanisms. Cancer Res 2003, 63:1752-1755.
51. Chou MW, Kong J, Chung KT, Hart RW: Effect of caloric restriction on the metabolic activation of xenobiotics. Mutat Res 1993, 295:223-235.
52. Stewart JW, Koehler K, Jackson W, Hawley J, Wang W, Au A, Myers R, Birt DF: Prevention of mouse skin tumor promotion by dietary energy restriction requires an intact adrenal gland and glucocorticoid supplementation restores inhibition. Carcinogenesis 2005, 26:1077-1084.
53. Thune I, Furberg AS: Physical activity and cancer risk: dose-response and cancer, all sites and site-specific. Med Sci Sports Exerc 2001, 33:S530-550; discussion S609-510.
54. Kushi LH, Doyle C, McCullough M, Rock CL, Demark-Wahnefried W, Bandera EV, Gapstur S, Patel AV, Andrews K, Gansler T: American Cancer Society Guidelines on nutrition and physical activity for cancer prevention: reducing the risk of cancer with healthy food choices and physical activity. CA Cancer J Clin 2012, 62:30-67.
55. Kushi LH, Byers T, Doyle C, Bandera EV, McCullough M, McTiernan A, Gansler T, Andrews KS, Thun MJ: American Cancer Society Guidelines on Nutrition and Physical Activity for cancer prevention: reducing the risk of cancer with healthy food choices and physical activity. $C A$ Cancer J Clin 2006, 56:254-281; quiz 313-254.
56. Byers T, Nestle M, McTiernan A, Doyle C, Currie-Williams A, Gansler T, Thun M: American Cancer Society guidelines on nutrition and physical activity for cancer prevention: Reducing the risk of cancer with healthy food choices and physical activity. CA Cancer J Clin 2002, 52:92- 119.

57. Guidelines on diet, nutrition, and cancer prevention: reducing the risk of cancer with healthy food choices and physical activity. The American Cancer Society 1996 Advisory Committee on Diet, Nutrition, and Cancer Prevention. CA Cancer J Clin 1996, 46:325-341.

58. Doyle C, Kushi LH, Byers T, Courneya KS, Demark-Wahnefried W, Grant B, McTiernan A, Rock CL, Thompson C, Gansler T et al: Nutrition and physical activity during and after cancer treatment: an American Cancer Society guide for informed choices. CA Cancer J Clin 2006, 56:323-353.

59. Brown JK, Byers T, Doyle C, Coumeya KS, Demark-Wahnefried W, Kushi LH, McTieman A, Rock CL, Aziz N, Bloch AS et al: Nutrition and physical activity during and after cancer treatment: an American Cancer Society guide for informed choices. CA Cancer J Clin 2003, 53:268-291.

60. Jiang $\mathrm{Y}$, Wang W. Potential mechnisms of cancer prevention by weight control. Biophy Rev Lett 2008, 3:421-437. 
61. Zhu M, Lee GD, Ding L, Hu J, Qiu G, de Cabo R, Bernier M, Ingram DK, Zou S: Adipogenic signaling in rat white adipose tissue: modulation by aging and calorie restriction. Exp Gerontol 2007, 42:733-744.

62. Fontana L, Weiss EP, Villareal DT, Klein S, Holloszy JO: Long-term effects of calorie or protein restriction on serum IGF-1 and IGFBP-3 concentration in humans. Aging Cell 2008, 7:681-687.

63. Lashinger LM, Malone LM, McArthur MJ, Goldberg JA, Daniels EA, Pavone A, Colby JK, Smith NC, Perkins SN, Fischer SM et al: Genetic reduction of insulin-like growth factor-1 mimics the anticancer effects of calorie restriction on cyclooxygenase-2-driven pancreatic neoplasia. Cancer Prev Res (Phila) 2011, 4:1030-1040.

64. Berrigan D, Lavigne JA, Perkins SN, Nagy TR, Barrett JC, Hursting SD: Phenotypic effects of calorie restriction and insulin-like growth factor-1 treatment on body composition and bone mineral density of C57BL/6 mice: implications for cancer prevention. In Vivo 2005, 19:667-674.

65. Rogozina OP, Bonorden MJ, Seppanen CN, Grande JP, Cleary MP: Effect of chronic and intermittent calorie restriction on serum adiponectin and leptin and mammary tumorigenesis. Cancer Prev Res (Phila) 2011, 4:568-581.

66. Gauffin Cano MP, Van Nieuwenhove C, Chaila Z, Bazan C, Gonzalez S: Effects of short-term mild calorie restriction diet and renutrition with ruminant milks on leptin levels and other metabolic parameters in mice. Nutrition 2009, 25:322-329.

67. Chacon F, Esquifino Al, Perello M, Cardinali DP, Spinedi E, Alvarez MP: 24-hour changes in ACTH, corticosterone, growth hormone, and leptin levels in young male rats subjected to calorie restriction. Chronobiol Int 2005, 22:253-265.

68. Stattin P, Bylund A, Rinaldi S, Biessy C, Dechaud H, Stenman UH, Egevad L, Riboli E, Hallmans G, Kaaks R: Plasma insulin-like growth factor-I, insulin-like growth factor-binding proteins, and prostate cancer risk: a prospective study. J Nat/ Cancer Inst 2000, 92:1910-1917.

69. Chan JM, Stampfer MJ, Giovannucci E, Gann PH, Ma J, Wilkinson P, Hennekens CH, Pollak M: Plasma insulin-like growth factor-I and prostate cancer risk: a prospective study. Science 1998, 279:563-566.

70. Pandini G, Vigneri R, Costantino A, Frasca F, Ippolito A, Fujita-Yamaguchi Y, Siddle K, Goldfine ID, Belfiore A: Insulin and insulin-like growth factor-I (IGF-I) receptor overexpression in breast cancers leads to insulin/IGF-I hybrid receptor overexpression: evidence for a second mechanism of IGF-I signaling. Clin Cancer Res 1999, 5:1935-1944.

71. Belfiore A, Pandini G, Vella V, Squatrito S, Vigneri R: Insulin/IGF-I hybrid receptors play a major role in IGF-I signaling in thyroid cancer. Biochimie 1999, 81:403-407.

72. DiGiovanni J, Bol DK, Wilker E, Beltran L, Carbajal S, Moats S, Ramirez A, Jorcano J, Kiguchi K: Constitutive expression of insulin-like growth factor-1 in epidermal basal cells of transgenic mice leads to spontaneous tumor promotion. Cancer Res 2000, 60:1561-1570.

73. Bol DK, Kiguchi K, Gimenez-Conti I, Rupp T, DiGiovanni J: Overexpression of insulin-like growth factor-1 induces hyperplasia, dermal abnormalities, and spontaneous tumor formation in transgenic mice. Oncogene 1997, 14:1725-1734.

74. Kenchappa P, Yadav A, Singh G, Nandana S, Banerjee K: Rescue of TNFalpha-inhibited neuronal cells by IGF-1 involves Akt and c-Jun N-terminal kinases. J Neurosci Res 2004, 76:466-474. 
75. Choi YS, Cho HY, Hoyt KR, Naegele JR, Obrietan K: IGF-1 receptor-mediated ERK/MAPK signaling

76. Kundu AK, Nagaoka M, Chowdhury EH, Hirose S, Sasagawa T, Akaike T: IGF-1 induces growth, survival and morphological change of primary hepatocytes on a galactose-bared polymer through both MAPK and beta-catenin pathways. Cell Struct Funct 2003, 28:255-263.

77. Yuan TL, Cantley LC: PI3K pathway alterations in cancer: variations on a theme. Oncogene 2008,

78. Engelman JA: Targeting PI3K signalling in cancer: opportunities, challenges and limitations. Nat 27:5497-5510.

79. Segrelles C, Lu J, Hammann B, Santos M, Moral M, Cascallana JL, Lara MF, Rho O, Carbajal S, Traag J et al: Deregulated activity of Akt in epithelial basal cells induces spontaneous tumors and heightened sensitivity to skin carcinogenesis. Cancer Res 2007, 67:10879-10888.

80. Vanamala J, Reddivari L, Radhakrishnan S, Tarver C: Resveratrol suppresses IGF-1 induced human colon cancer cell proliferation and elevates apoptosis via suppression of IGF-1R/Wnt and activation of p53 signaling pathways. BMC Cancer 2010, 10:238.

81. Hursting SD, Switzer BR, French JE, Kari FW: The growth hormone: insulin-like growth factor 1 axis is a mediator of diet restriction-induced inhibition of mononuclear cell leukemia in Fischer rats. Cancer Res 1993, 53:2750-2757.

82. Xie L, Jiang Y, Ouyang P, Chen J, Doan H, Herndon B, Sylvester JE, Zhang K, Molteni A, Reichle M et al: Effects of dietary calorie restriction or exercise on the PI3K and Ras signaling pathways in the skin of mice. J Biol Chem 2007, 282:28025-28035.

83. Lu J, Xie L, Sylvester J, Wang J, Bai J, Baybutt R, Wang W: Different gene expression of skin tissues between mice with weight controlled by either calorie restriction or physical exercise. Exp Biol Med (Maywood) 2007, 232:473-480.

84. Moore T, Beltran L, Carbajal S, Strom S, Traag J, Hursting SD, DiGiovanni J: Dietary energy balance modulates signaling through the Akt/mammalian target of rapamycin pathways in multiple epithelial tissues. Cancer Prev Res (Phila) 2008, 1:65-76.

85. Pfaffenbach KT, Pong M, Morgan TE, Wang H, Ott K, Zhou B, Longo VD, Lee AS: GRP78/BiP is a novel downstream target of IGF-1 receptor mediated signaling. J Cell Physiol 2012, 227: 380311.

86. Cohen HY, Miller C, Bitterman KJ, Wall NR, Hekking B, Kessler B, Howitz KT, Gorospe M, de Cabo $\mathrm{R}$, Sinclair DA: Calorie restriction promotes mammalian cell survival by inducing the SIRT1 deacetylase. Science 2004, 305:390-392.

87. Haydon AM, Macinnis RJ, English DR, Morris H, Giles GG: Physical activity, insulin-like growth factor 1 , insulin-like growth factor binding protein 3 , and survival from colorectal cancer. Gut 2006, 55:689-694.

88. Fairey AS, Courneya KS, Field CJ, Bell GJ, Jones LW, Mackey JR: Effects of exercise training on fasting insulin, insulin resistance, insulin-like growth factors, and insulin-like growth factor binding proteins in postmenopausal breast cancer survivors: a randomized controlled trial. Cancer Epidemiol Biomarkers Prev 2003, 12:721-727. 
89. McTiernan A, Sorensen B, Yasui Y, Tworoger SS, Ulrich CM, Irwin ML, Rudolph RE, Stanczyk FZ, Schwartz RS, Potter JD: No effect of exercise on insulin-like growth factor 1 and insulin-like growth factor binding protein 3 in postmenopausal women: a 12-month randomized clinical trial. Cancer Epidemiol Biomarkers Prev 2005, 14:1020-1021.

90. Leung PS, Aronson WJ, Ngo TH, Golding LA, Barnard RJ: Exercise alters the IGF axis in vivo and increases p53 protein in prostate tumor cells in vitro. J Appl Physiol 2004, 96(2):450-454.

91. Barnard RJ, Leung PS, Aronson WJ, Cohen P, Golding LA: A mechanism to explain how regular exercise might reduce the risk for clinical prostate cancer. Eur J Cancer Prev 2007, 16:415-421.

92. Padovani M, Lavigne JA, Chandramouli GV, Perkins SN, Barrett JC, Hursting SD, Bennett LM, Berrigan D: Distinct effects of calorie restriction and exercise on mammary gland gene expression in C57BL/6 mice. Cancer Prev Res (Phila) 2009, 2:1076-1087.

93. Ouyang P, Jiang Y, Doan HM, Xie L, Vasquez D, Welti R, Su X, Lu N, Herndon B, Yang SS et al: Weight Loss via exercise with controlled dietary intake may affect phospholipid profile for cancer prevention in murine skin tissues. Cancer Prev Res (Phila) 2010, 3:466-477.

94. Jiang Y, Ma H, Su X, Chen J, Xu J, Standard J, Lin D, Wang W. IGF-1 mediates exercise-induced phospholipid alteration in the murine skin tissues. Journal of Nutrition and Food Science 2012; S2-003.

95. Moore T, Carbajal S, Beltran L, Perkins SN, Yakar S, Leroith D, Hursting SD, Digiovanni J: Reduced susceptibility to two-stage skin carcinogenesis in mice with low circulating insulin-like growth factor I levels. Cancer Res 2008, 68:3680-3688.

96. Lashinger LM, Malone LM, Brown GW, Daniels EA, Goldberg JA, Otto G, Fischer SM, Hursting SD: Rapamycin partially mimics the anticancer effects of calorie restriction in a murine model of pancreatic cancer. Cancer Prev Res (Phila) 2011, 4:1041-1051. 